\title{
Effect Of Light Environment On Harvest Quality And Postharvest Behavior Of Minimally Processed Sweet Pepper
}

\author{
Diana Frezza, $M S c$. \\ University of Buenos Aires, Argentina. \\ Aina M. Pons Miquel \\ Escola Técnica Superior d’Enginyeria Agronòmica i del Medi Rural. \\ Universitat Politècnica de València, España \\ Veronica Logegaray \\ Adrian P. Leon, MSc. \\ Angel Chiesa, $D$. \\ University of Buenos Aires, Argentina
}

doi: 10.19044/esj.2016.v12n15p406 URL:http://dx.doi.org/10.19044/esj.2016.v12n15p406

\begin{abstract}
The aim of this study was to evaluate the effect of two light environments on two maturity stages of sweet pepper and the postharvest behavior of minimally processed product using passive modified atmosphere. The size and fruit morphology were measured at harvest. Overall visual quality, gas concentration inside the bags, weight loss, soluble solids, firmness, electrolyte leakage, carotenoids and ascorbic acid were determined during the storage period. Results showed that quality parameters were affected by radiation and processing. Shaded pepper fruits showed higher water content and lower size compared to fruits exposed to full radiation. Fruit nutritional value was maintained, but after six days was not marketable. Visual quality of intact fruit was not affected without differences between treatments. Shelf life processed red fruits as julienne was reduced, being the worst performing during storage. Post-harvest visual quality was in relation to gases composition $\left(\mathrm{O}_{2}\right.$ and $\left.\mathrm{CO}_{2}\right)$ inside the trays.
\end{abstract}

Keywords: Capsicum sp, radiation, modified atmosphere, appearance, nutrition value. 


\section{Introduction:}

Sweet pepper is widely distributed in Argentine. Abiotic stress by high or low temperature, water deficit, salinity, excess or reduction of radiation has great influence on the yield and quality of the crop.

Fruits and vegetables quality depend on preharvest, harvest and postharvest conditions. Radiation level is reported as the first and most important climate factor. Radiation intensity has the ability to modify plant and fruit morphology and the fruit composition. According to Azcón-Bieto and Heel (2000) leaves grown in weak light conditions may reach a greater surface area than those developed in bright light. Jaimez and Rada (2006) found that plants without shade and under $40 \%$ shade showed no significant differences, Jaimez et al. (2010) concluded that shadow under 40\% increased production as a consequence of increasing of fruit number and weight per plant.

Vitamin C (including ascorbic acid + dehydroascorbic acid) is one of the most important nutritional value parameter and it has diverse biological activity in the human body. Sweet pepper fruit provides vitamin C and vitamin A, flavonoids and antioxidants too (Lee and Kader, 2000).

There are dramatic qualitative and quantitative changes during sweet pepper ripening (Rodriguez-Amaya et al., 2008) like carotenoids synthesis (Hornero-Méndez et al., 2000), and their accumulation (Howard et al., 1994; Markus et al., 1999; Navarro et al., 2006; Xavier and Pérez-Gálvez, 2016).

The aim of this study was to evaluate the effect of two light environments on sweet pepper harvest and on their postharvest behavior in two stages of pepper fruit maturity, minimally processed (intact and julienne), stored in passive modified atmosphere in refrigerated chamber.

\section{Material and methods:}

\section{Plant Material}

This work was carried out in the experimental field of the Department of Horticulture, in a parabolic, metallic NE-NW oriented greenhouse (34 $\left.58^{\mathrm{a}} 31^{\prime}\right)$. Pepper plants (Capsicum annuum L.cV Yatasto) were transplanted in plastic containers filled up with a mixture of substrate (1perlite:1peat). Plant density was 2 plants $/ \mathrm{m}^{2}$. Fertirrigation with a complete nutrient solution was applied. The light treatments were: a) plants with shade screen (50 \%) and b) unshaded plants (100\%). Plants were conducted to 3 stems. Air temperature $\left({ }^{\circ} \mathrm{C}\right)$, substrate temperature $\left({ }^{\circ} \mathrm{C}\right)$, relative humidity (\%) and radiation intensity (lum/feet ${ }^{2}$ ) were recorded every hour.

At harvest, fruits were classified as: a) inmature green fruit and b) mature red fruit. Fruits harvested were separated in two groups: a) intact fruits and b) cut fruits into julienne $(12 \times 1 \mathrm{~cm})$ manually with a steel knife properly sharpened. All treatments were packed in passive modified 
atmosphere using an expanded polystyrene tray covered with PVC film with the following properties: $0.0177 \mathrm{~mm}$ thickness, oxygen and carbon dioxide permeability 11.232 and $48.552 \mathrm{~cm}^{3} / \mathrm{m}^{2} /$ atm/day respectively, and water permeability of $40 \mathrm{~g} / \mathrm{m}^{2} /$ day. All trays were stored in refrigerated chamber at $10^{\circ} \mathrm{C}$ for 12 days. Thirty fruits per treatment were used.

\section{Measurements}

Fruits morphology: length, width and thickness of fruit were measured. Numbers of cores and fruit weight were recorded. Results were expressed in the following units according to their respective magnitudes: centimeter $(\mathrm{cm})$, square feet $\left(\mathrm{cm}^{2}\right)$, cubic centimeter $\left(\mathrm{cm}^{3}\right)$ and gram $(\mathrm{g})$.

Dry matter: Fruits were dried in an oven for 48 hours at $75^{\circ} \mathrm{C}$ to constant weight, and dry matter (\%) was calculated.

Overall visual quality: according to Özden and Bayindirli scale (2002).

Surface colour: Three colour determinations along the equatorial axis were taken for each fruit (Minolta CR 300 colorimeter). Colourimeter parameters: the lightens $L^{*}$ ranges from no reflection $\left(L^{*}=0\right.$; Black) to perfect diffuse reflection ( $\mathrm{L}^{*}=100$, white), $\mathrm{a}^{*}$ is a positive or negative coordinate defining a locus relative to a purplish-red-bluish-green axix, and $\mathrm{b}^{*}$ is positive or negative coordinate defining a locus relative to a yellowblue axis. Numerical values of $\mathrm{a}^{*}$ and $\mathrm{b}^{*}$ are converts into saturation variable or chroma $(\mathrm{C}=\mathrm{a} 2+\mathrm{b} 2) 1 / 2$, and a mesure of chromaticity, the hue angle $\left(\mathrm{h}^{\mathrm{o}}=\right.$ arctanb*/a*). (Frezza et al., 2011).

Gas concentration $\left(\mathrm{O}_{2}\right.$ and $\left.\mathrm{CO}_{2}\right)$ inside the packing (\%): a Dansensor gas analyser (Frezza et al., 2010) was used.

Firmness $(\mathrm{kg})$ was determined with an Effegi FT 327 penetrometer equipped with a $7.9 \mathrm{~mm}$ tip.

Electrolyte leakage (\%) was analyzed at the end of storage according to the method described by Frezza et al., 2011.

Soluble solids ( ${ }^{\circ}$ Brix) were measured using a refractometer (Atago).

Weight loss (\%): between harvest and at the end of the storage period was calculated.

Carotenoids (mg/g FW) were determined according Nagata and Yamashita (1992).

Ascorbic acid (mg AA/100 g FW) was measured using a technique described by Valente et al. (2011).

Statistical analysis. Experimental design was completely randomized with factorial arrangement with following factors: radiation level, maturity stage, processing degree and storage time with three replicates for each treatment. Analysis of the results was performed by ANOVA and means were compared by Tukey test at 5 \% (Statistical software: Infostat). 


\section{Results and discussion:}

Radiation level and fruit morphology. The environmental factors affected size and shape of fruits and the product postharvest performance. Radiation intensity during growth and maturity stage had significant effect on the measured parameters of size and morphology fruit (Table 1). Green fruits were larger than red fruits, but there were no significant differences in width. Radiation level affected these two dimensions regardless of the maturity stage. Unshaded fruits were larger and heavier than shaded fruits. Furthermore, it is related to dry matter content. Fruits exposed to higher radiation level accumulated more dry matter. Potential production of a crop, expressed as total dry matter and considering that no other limiting factor will depend on the amount of radiation intercepted. Linear relationship was established between potential productivity and the amount of intercepted radiation (Maroto, 2000). Neither thickness nor the number of cores was affected by the factors evaluated. Probably; genetic factor has a great influence on these parameters.

Table 1. Length $(\mathrm{cm})$, width $(\mathrm{cm})$, thickness of flesh fruit $(\mathrm{cm})$, and weight $(\mathrm{g})$ of pepper fruits harvested at two stages of maturity (green and red) exposed to two radiation levels (50

\begin{tabular}{|lccccc|}
\hline $\begin{array}{l}\text { Maturity } \\
\text { stage }\end{array}$ & Radiation & $\begin{array}{c}\text { Length } \\
(\mathbf{c m})\end{array}$ & $\begin{array}{c}\text { Width } \\
(\mathbf{c m})\end{array}$ & $\begin{array}{c}\text { Thickness } \\
(\mathbf{c m})\end{array}$ & Weight (g) \\
\hline Green & $100 \%$ & $11.86 \mathrm{a}$ & $7.18 \mathrm{a}$ & $0.43 \mathrm{a}$ & $175.66 \mathrm{a}$ \\
\hline Green & $50 \%$ & $11.46 \mathrm{a}$ & $6.39 \mathrm{~b}$ & $0.42 \mathrm{a}$ & $133.41 \mathrm{~b}$ \\
\hline Red & $100 \%$ & $11.13 \mathrm{a}$ & $6.86 \mathrm{~b}$ & $0.41 \mathrm{a}$ & $149.13 \mathrm{ab}$ \\
\hline Red & $50 \%$ & $10.03 \mathrm{~b}$ & $6.61 \mathrm{~b}$ & $0.41 \mathrm{a}$ & $128.62 \mathrm{~b}$ \\
\hline
\end{tabular}

Different letters means significant difference $(\mathrm{p} \leq 0.05)$

Fruit appearance. The appearance of a food product is the most obvious attribute for the consumer, and powerfully affects the decision to buy (Toivonen and Brummell, 2008). Fruit appearance changes during storage period were evaluated throughout overall visual quality. Thus, statistical analysis showed significant differences between treatments $(p \leq 0.0001)$, except for level of radiation. In processed fruits overall visual quality decline progressively over storage period and the product was not marketable at the end of storage. Browning of plant tissue, the occurrence of Alternaria sp. and the water condensation inside of packaging were the main factors that affected the visual quality of minimally processed peppers.

Fruit color changes is the result of the chlorophyll degradation and carotenoids synthesis affected by temperature and lighting to which the fruit was exposed (Perez-Lopez et al., 2007). Red fruit exposed to $100 \%$ of the radiation received showed more opaque colours $(\mathrm{L} * 50 \%=33.76, \mathrm{~L} * 100 \%$ $=31.37)$, and also showed lower values of $b *$ and $h$. 
Thus, the radiation determined a chlorophyll loss, greater for fruit unshaded. These were more opaque than 50\% fruits exposed radiation fruits.

Type of minimally processed treatments. Cut into strips determined an intensification of the colour of the fruit (values higher $\mathrm{C}$ ) and slightly more yellow ( $\left.\mathrm{b}^{*}\right)$. Intact fruit showed lower $\mathrm{h}^{\mathrm{o}}$, while the opposite occurred in green pepper julienne, associated with the loss of chlorophyll. According to Guerra et al. (2011) the fruit red colour enhances during storage period (a* value increased to $24.65 \%$ in 10 days of refrigerated storage at $8^{\circ} \mathrm{C}$ ). In our experiment, red fruits were less affected compared with Guerra et al. (2011), an increase of $13 \%$ in a* value was recorded). On the other hand, Smith et al. (2006) reported in your research the relationship between water losses with brightness loses. However, in this experience has not been possible to correlate weight losses with any colour coordinates.

Package gas atmosphere. Gas concentration inside the packaging was modified significantly $(\mathrm{p}<0.01)$ by the effect of maturity stage, processing and storage period. On the first day, $\mathrm{O}_{2}$ decreased $11 \%$ and $\mathrm{CO}_{2}$ increased 60-98\% compared to the initial gas concentration. These changes were probably due to tissue acclimatization to this condition in early hours, since there was no remarkable change for intact fruits during rest of storage. The situation was completely different to processed fruits. Gas concentration inside the package was affected clearly by the maturity stage and storage period. Results showed that processed fruits increased the respiration rate due to an increasing of the surface area exposed (Figure 1). Furthermore, respiration acceleration in red fruits was higher than green fruits because the advanced maturity stage. Gas concentrations were below $15 \%$ and above 6 $\%$ for $\mathrm{O}_{2}$ and $\mathrm{CO}_{2}$ respectively. It has been shown that storage life was extended by modified atmosphere packaging (Ward, 2016) and processing of vegetables induces rapid deterioration in order of three to five times to the intact product (Wiley, 1997).
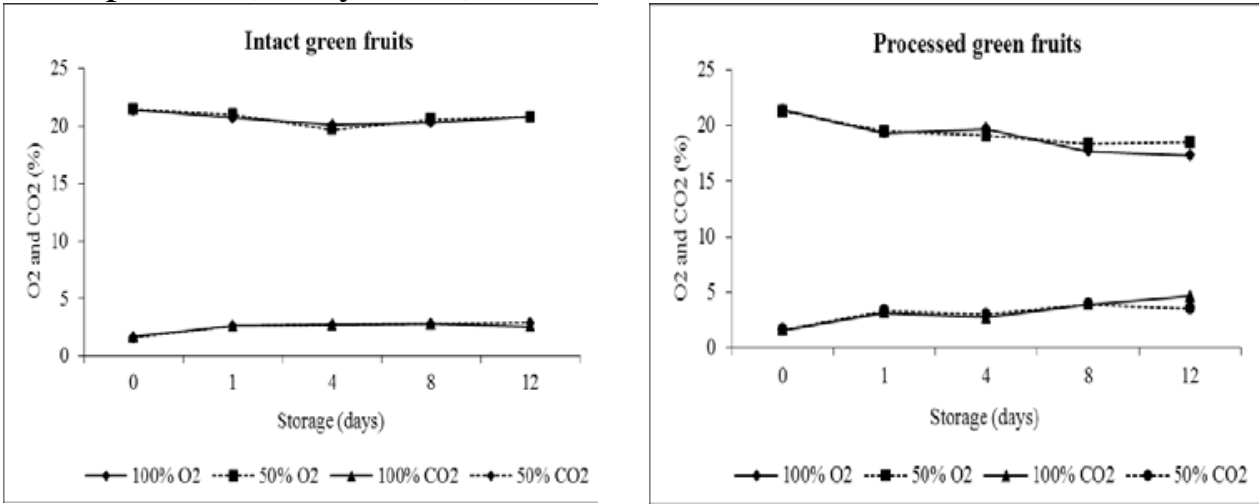

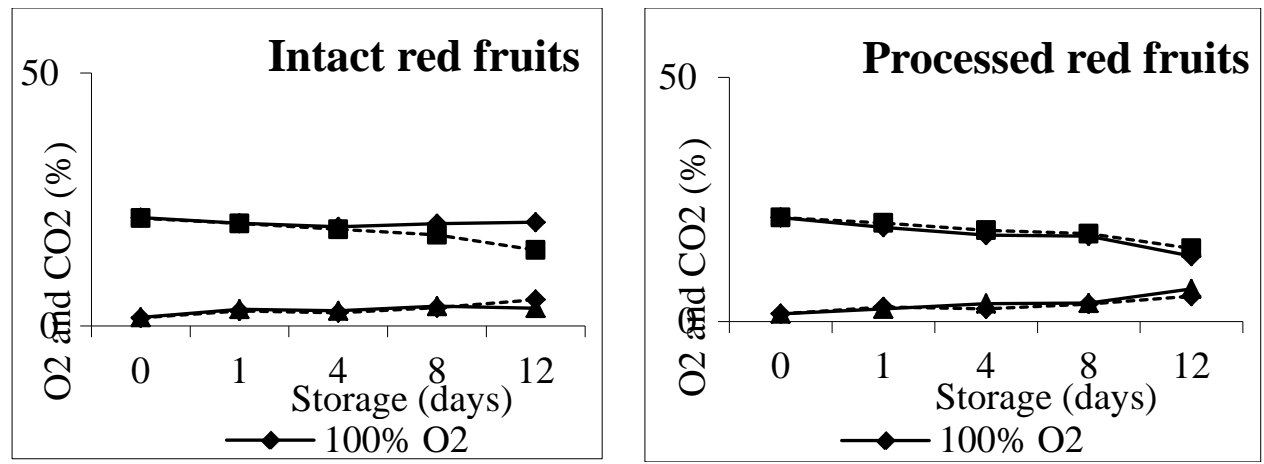

Figure 1. Gas (oxygen and carbon dioxide) concentration (\%) inside the container with pepper fruits exposed to two solar radiation levels (50\% and $100 \%$ ), at two maturity stages

(green and red), intact and minimally processed and refrigerated at $10{ }^{\circ} \mathrm{C}$ for 12 days.

Water loss. The main physiological factor that impact negatively during storage and marketing is water loss, which is evaluated by weight loss (Smith et al., 2006; Raffo et al., 2007). Weight loss changes between treatments were observed. Statistical analysis demonstrated that the magnitude of this loss depends directly on maturity stage, processed, storage period and radiation conditions during season crop.

At the end of storage, processed red fruits cultivated without shade reached the greatest weight loss $(6.37 \%)(\mathrm{p} \leq 0.05)$. By contrast, whole green fruit regardless of radiation treatment had the lowest weight loss $(2.21 \%)$, although the differences with the other treatments were not significant. Raffo et al. (2007) found that fruit pepper is susceptible to serious loss of water due to high area/volume ratio, although these losses are substantially reduced in plastic packaging. According to Gonzalez-Aguilar and Tiznado (1993), the first symptoms of wilt appear from weight loss of $5 \%$ of the initial fruit weight. In this research, only red fruits processed and exposed to full radiation exceeded that threshold. These fruits lost weight and showed the appearance of Alternaria alternate that decreased product quality to unmarketable levels.

Soluble solids. Sugars represent the main fraction of total soluble solids of the fruit, reaching almost $60 \%$ of dry matter in red pepper (Raffo et al., 2007). Soluble solids loss during storage is normal because of cellular respiration in postharvest (Özden and Bayindirli, 2002). According to Raffo et al. (2008) radiation during the crop and minimal processing did not affect soluble solid content, whereas, maturity stage and storage period affected reduction and accumulation.

Red fruits had higher values (twice, approximately) than green (Figure 2). Taddesse et al. (2002) reported that the change of colour and total soluble solids are very good index of maturity stage of sweet pepper. In the 
same work, $6^{\circ}$ Brix is set as the minimum for optimally ripe fruits of $\mathrm{cv}$. "Sunday.
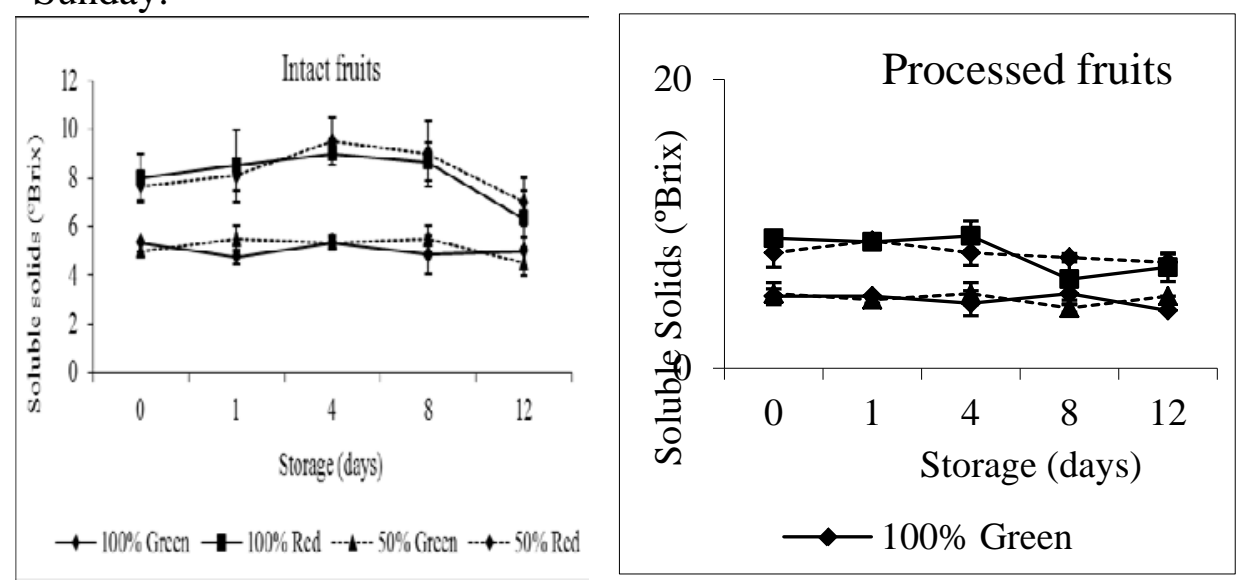

Figure 2. Soluble solids ( ${ }^{\circ}$ brix) for pepper fruits exposed to two solar radiation levels (50\% and $100 \%$ ), at two maturity stages (green and red), intact and minimally processed, refrigerated at $10^{\circ} \mathrm{C}$ for 12 days.

Initial content of fruits decreased at the end of the storage. Two phases are recognized during storage: a first phase in which accumulate soluble solids for 4-5 days, reaching a maximum relative concentration followed by a second phase that begin to decay. The increase in the soluble solids during the first days of storage may be due to concentration effect because of water loss in those days (González-Aguilar and Tiznado, 1993; Özden and Bayindirli, 2002; Raffo et al., 2008). Subsequent decreasing is due to its use as substrate in the process of cellular respiration (Conesa et al., 2007).

Firmness. Firmness is one of many attributes used to determine the texture of fruits and vegetables (Lin and Zhao, 2007). In our experiment maturity stage was affected by firmness, and as it was expected, green fruits showed greater resistance to penetration than red fruits as consequence of firmness increase of plant tissues. Tadesse et al. (2002), which measured the firmness of the fruits during plant development observed that the strength of green fruit increased with fruit size (fresh weight) until colour change occurred when firmness decreased. Radiation levels did not affect fruit firmness, but storage period had a significant effect on firmness $(p=0.0052)$. Guerra et al. (2011) reported that during storage certain biochemical and structural modification occurs that cause changes in the texture of peppers.

Modified atmosphere packaging effect on firmness should not be underestimated. Özden and Bayindirli, (2002) and Raffo et al. (2007) reported that pepper fruits in modified atmosphere showed no significant changes in firmness over storage period. 
In general, electrolyte leakage is an indirect measurement of the properties of the cell membrane (Fan and Sokorai, 2005) and it is associated with the onset of symptoms due to chilling injury of plant tissues. Temperature at which they begin to appear in pepper is $7^{\circ} \mathrm{C}$ (Lim et al., 2007). Refrigerated storage of these trials resulted without chilling injury in the fruit.

Carotenoids. Carotenoids content showed significant differences $(\mathrm{p}<0.0001)$ between red and green fruits, being approximately double for red (25.95 and $13.06 \mu \mathrm{g} / \mathrm{g}$ fresh weight respectively). Our results are agree with Howard et al. (1994), Markus et al. (1999) and Navarro et al. (2006).

Processing was carried out at room temperature in the minimun time possible; however, carotenoid degradation was inevitable. Rodriguez-Amaya et al., (2008) reported that exposure to light can promote photodegradation of carotenoids.

Many environmental factors affect the biosynthesis and accumulation of carotenoids (Britton and Hornero-Méndez, 1997) although genetic is the main. Factor such as temperature, light regime, water availability, soil quality and pollution, have a great influence on growth and also affect carotenoid content.

Regarding green fruits, storage period had a significant influence in the pigment concentration, particularly in a loss ranging from $29-45 \%$.

Ascorbic acid Lee and Kader (2000) reported that many factors, pre and post harvest, influence the content of vitamin $\mathrm{C}$ in many horticultural species. Among them, genetic factors, climatic conditions, cultural practices during growing season, maturity at harvest and handling and postharvest conditions were mentioned. In this study, levels of ascorbic acid ranged from 21.31 to $95.58 \mathrm{mg} / 100 \mathrm{~g}^{-} \mathrm{FW}$ (Figure 3). No significant differences between maturity stages were detected; however, it was detected for the rest of the analyzed factors.

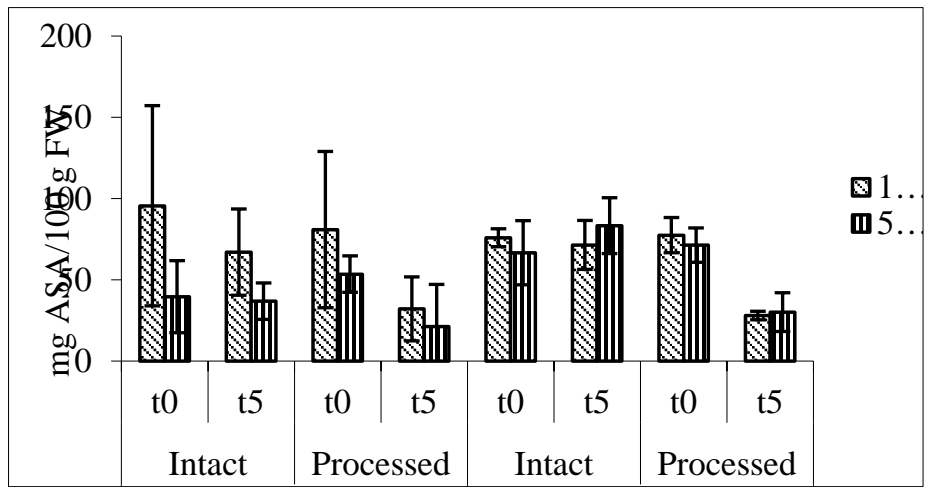

Figure 3. Ascorbic acid (mg/ $100 \mathrm{~g} \mathrm{FW)} \mathrm{for} \mathrm{pepper} \mathrm{fruits} \mathrm{exposed} \mathrm{to} \mathrm{two} \mathrm{levels} \mathrm{of} \mathrm{solar}$ radiation, at two different maturity stages, minimally processed and refrigerated at $10^{\circ} \mathrm{C}$ for 12 days. 
Dependence of ascorbic acid content and maturity of fruits has not been clearly established. Ghasemnezhad et al. (2011) evaluated five genotypes and found that green fruits contained higher levels of ascorbic acid than red fruits. Navarro et al. (2006) obtained similar findings for the cultivar "Orlando", by contrast, Howard et al. (1994).

Relative to radiation level during growth cycle. Fruits exposed to full radiation had higher concentration of ascorbic acid in accordance with Howard et al. (2000). Processing operation clearly affected ascorbic acid concentration, promoting its degradation by nearly $35 \%$, according to Lee and Kader (2000). In addition, storage period was the factor that had the greatest influence on this parameter.

Vitamin $C$ is the generic term for all compounds which share the same biological activity of ascorbic acid. Ascorbic acid is the main biologically active form, but L-dehydroascorbic acid, and oxidation product, also exhibits the same biological activity. L-dehydroascorbic is easily converted to ascorbic acid within the human body, it is important to measure both to know the real content of vitamin C in fruits and vegetable (Lee \& Kader, 2000; Mazurek, \& Pankiewicz, 2012).

\section{Conclusion:}

According the radiation during the crop growth, maturity at harvest and type of processed, shaded pepper fruits showed higher water content and less development compared to fruits exposed to full radiation. Fruit nutritional value was maintained till sixth day of storage. Both ascorbic acid and carotenoids were affected by the degree of maturity as well as processing, storage time and temperature. The radiation had only effect on ascorbic acid content, increasing it. Visual quality of intact fruit was not affected without differences between treatments. Shelf life of processed red fruits (julienne) was reduced, being the worst performing during storage. Post-harvest visual quality was highly related to gases composition $\left(\mathrm{O}_{2}\right.$ and $\mathrm{CO}_{2}$ ) inside the trays.

\section{References:}

Azcón Bieto, J. \& Talón, M. (2000). Fundamentos de Fisiología Vegetal. (pp 30-34; 203-216). Madrid, España: McGraw-Hill/Interamericana, Edicions Universitat de Barcelona.

Britton, G. \& Hornero-Méndez, D. (1997). Carotenoids and colour in fruit and vegetables. In F. Tomás-Barberán, \& R. Robins: Phytochemistry of fruit and vegetables (pp 11-47). New York: Oxford University Press.41.

Conesa, A., Artés-Hernández, F., Geysen, S., Nicolaï, B., \& Artés, F. (2007). High oxygen combined with high carbon dioxide improves microbial and 
sensory quality of fresh-cut peppers. Postharvest Biology and Technology, 43, 230-237.

Fan, X., \& Sokorai, K. (2005). Assessment of radiation sensivity of fresh-cut vegetables using electrolyte leakage measurement. Postharvest Biology and Technology, 36, 191-197.

Frezza, D., Leon, A., Logegaray, V. \& Chiesa, A. (2011). Postharvest quality of green onion grown in soilless culture: Effect of packaging and storage temperature. Agricultura Tropica et Subtropica, 44 (1), 11-17.

Frezza, D., Logegaray, V., León, A., Harris, M., \& Chiesa, A. (2010). Rocket (Eruca sativa Mill.) quality affected by preharvest and postharvest factors. Acta Horticulturae, 875, 357-364.

Ghasemnezhad, M., Sherafati, M., \& Ali Payvast, G. (2011). Variation in phenolic compounds, ascorbic acid and antioxidant activity of five coloured bell pepper (Capsicum annuum) fruits at two different harvest time. Journal of Functional Foods, 3, 44-49.

González-Aguilar, G., \& Tiznado, M. (1993). Postharvest physiology of bell peppers in low density polyethylene bags. Lebensmittel Wissenschaft und Technologie, 22, 450-455.

Guerra, M., Magdaleno, R., \& Casquero, P. (2011). Effect of site and storage conditions on quality of industrial fresh pepper. Scientia Horticulturae, 130 (1), 141-145.

Hornero-Méndez, D., Gómez-Ladrón de Guevara, R., \& Mínguez-Mosquera, M. (2000). Carotenoid biosynthesis changes in five red pepper (Capsicum annuum L.) cultivars during ripening. Cultivar selection for breeding. Journal of Agricultural and Food Chemistry, 48, 3857-3864.

Howard, L., Smith, R., Wagner, A., Villalon, B., \& Burns, E. (1994). Provitamin A and ascorbic acid content of fresh pepper cultivars (Capsicum annuum L.) and processed jalapeños. Journal of Food Science, 59, 362-265.

Howard, L., Talcott, S., Brenes, C., \& Villalón, B. (2000). Changes in phytochemical and antioxidant activity of selected pepper cultivars (Capsicum species) as influenced by maturity. Journal of Agricultural and Food Chemistry, 48, 1713-1720.

Jaimez, R., Añez, B., \& Espinoza, W. (2010). Desfloración: Su efecto sobre el aborto de estructuras reproductivas y rendimiento en pimentón (Capsicum annumm L.). Revista Facultad de Agronomía, 27, 418-432.

Jaimez, R. E., \& Rada, F. (2006). Flowering and fruit production dynamics of sweet pepper (Capsicum chinense Jacq) under different shade conditions in a humid tropical region. Journal of Sustainable Agriculture, 27, 97-108.

Lee, S., \& Kader, A. (2000). Preharvest and postharvest factors influencing vitamin $\mathrm{C}$ content of horticultural crops. Postharvest Biology and Technology, 20, 207-220. 
Lim, C.S., Kang, S.M., \& Cho, J.L. (2007). Bell pepper (Capsicum annuum L.) fruits are susceptible to chilling injury at the breaker stage of ripeness. HortScience, 42 (7), 1659-1664.

Lin, D., \& Zhao, Y. (2007). Innovations in development and application of edible coatings for fresh and minimally processed fruits and vegetables. Comprehensive Reviews in Food Science and Food Safety, 6, 60-75.

Márkus, F., Daood, H., Kapitany, J., \& Biacs, P. (1999). Change in the carotenoid an antioxidant content of spice red pepper (paprika) as a function of ripening and some technological factors. Journal of Agricultural and Food Chemistry, 47, 100-107.

Maroto, J. (2000). Elementos de Horticultura General. Madrid: Ed. MundiPrensa.

Mazurek, A., \& Pankiewicz, U. (2012). Changes of dehydroascorbic acid content in relation to total content of vitamin $C$ in selected fruits and vegetables. Acta Scientiarum Polonorum, Hortorum Cultus, 11 (6), 169-177. Nagata, M., \& Yamashita, I. (1992). Simple method for simultaneous determination of chlorophyll and carotenoids in tomato fruit. Journal of Japanese Society of Food Science and Technology, 39, 925-928.

Navarro, J., Flores, P., Garrido, C., \& Martínez, V. (2006). Changes in the content of antioxidant compounds in pepper fruits at different ripening stages, as affected by salinity. Food Chemistry, 96, 66-73.

Özden, Ç., \& Bayindirli, L. (2002). Effects of combitional use of controlled atmosphere, cold storage and edible coating applications on shelf life and quality attributes of green peppers. European Food Research and Technology, 214, 320-326.

Pérez-López, A., López-Nicolás, J., Núñez-Delicado, E., del Amor, F., \& Carbonell-Barrachina, A. (2007). Effects of agricultural practices on colour carotenoids composition and minerals contents of sweet peppers, cv. Almuden. Journal of Agricultural and Food Chemistry, 55, 8158-8164.

Raffo, A., Baiamonte, I., \& Paoletti, F. (2008). Changes in antioxidants and taste-related compounds content during cold storage of fresh-cut red sweet peppers. European Food Research Technology, 226, 1167-1174.

Raffo, A., Baiamonte, I., Nardo, N., \& Paoletti, F. (2007). Internal quality and antioxidants content of cold-stored red sweet peppers as affected by polyethylene bag packaging and hot water treatment. European Food Research Technology, 225, 395-405.

Rodriguez-Amaya, D., Kimura, M., Godoy, H., \& Amaya-Farfan, J. (2008). Updated Brazilian database on food carotenoids: Factors affecting carotenoid composition. Journal of Food Composition and Analysis, 21, 445-463.

Ryiski, I., \& Spigelman, M. (1986). Effect of shading on plant development, yield and fruit quality of sweet pepper grown under conditions of high temperature and radiation. Scientia Horticulturae, 29, 31-35. 
Smith, D.L., Stommel, J.R., Fung, R., Wang, C., \& Whitaker, B. (2006). Influence of cultivar and harvest method on postharvest storage quality of pepper. Postharvest Biology and Technology, 42, 243-247.

Tadesse, T., Hewett, E.W., Nichols, M.A., \& Fisher, K.J. (2002). Changes in physicochemical attributes of sweet pepper cv. Domingo during fruit growth and development. Scientia Horticulturae, 93, 91-103.

Toivonen, P., \& Brummell, D. (2008). Biochemical bases of appearance and texture changes in fresh-cut fruit and vegetables. Postharvest Biology and Technology, 48,1-14.

Valente, A., Albuquerque, T.G., Sanches-Silva, A., \& Costa, H.S. (2011). Ascorbic acid content in exotic fruits: A contribution to produce quality data for food composition database. Food Research International, 44, 2237-2242. Ward,G. (2016) Modified Atmosphere Packaging for Extending Storage Life of Fresh Fruits and Vegetables, In Reference Module in Food Science. Elsevier.

Wiley, R.C. (1997). Frutas y hortalizas mínimamente procesadas y refrigeradas. Zaragoza: Acribia S.A.

Xavier, A.A.O. \& Pérez-Gálvez, A. 2016. Peppers and Chilies. In: Encyclopedia of Food and Health (pp 301-306). Oxford, England: Academic Press. 